https://doi.org/10.31874/2520-6702-2021-12-2-221-233

УДК 321(100)

Dasaolu, Babajide Olugbenga

ORCID: 0000-0003-0369-9630

Department of Philosophy, Olabisi Onabanjo University, Ago-Iwoye, Ogun State, Nigeria. dasaolu.babajide@oouagoiwoye.edu.ng

\title{
Education and Social Change in the Works of Karl Popper and George Orwell: A Pedagogy of Caution for Marxists in Africa
}

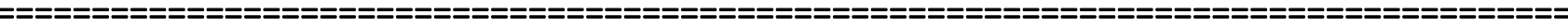

Some decades ago, the Brazilian scholar Paulo Freire wrote his Pedagogy of the Oppressed to indicate the rationale for social change and the place of education in that affair. This study takes a leaf from Freire's work to dialogue how authentic and people-centered social change can be attained in Africa. In contemporary African political scholarship, scholars are divided over the methodology of attaining social change. Some take inspiration from the thoughts of Karl Popper who maintains that there are two approaches toward social change: The Piecemeal and the Utopian. It is also the case that Popper puts trust and emphasis on the former when he doubts and opposes the latter, which appeals mostly to Marxists in Africa. Since it has become a dominant locus for almost all of African scholars to take a Marxist approach in their articulation and struggle for social change, this study intends to serve as a caution. Caution because, it is an open secret that Marxists of African descent have been very critical and bitter of Popper's version of social change for being reactionary; that it is a viewpoint which aims to preserve an exploitative status quo. When the onus of this study is to defend Popper against such uncharitable misrepresentations, it forays into George Orwell's classic Animal Farm, for succor. Orwell's fable is a revelation of the dangers that may emanate from Utopian social engineering in real life scenario. The unfortunate totalitarian era that greeted the animals in the aftermath of their violent and bloody revolution in Manor Farm is not only a lesson but serves to initiate the discourse regarding the intention and integrity of those leading social change and struggles across Africa. It is precisely for this reason that this essay beckons on Africans to initiate a platform for social change that will be void of violence and bloodshed. By taking a pedagogy approach to education, this research would have been able to explore the ways through which education can contribute to the plight of social change and social stability in Africa.
\end{abstract}

Keywords: Karl Popper, Social Change, Marxism, Africa, George Orwell

\section{Introduction}

It is a general understanding that education is one of the bedrocks for the emergence of sound minds that will transform society for good. What this means is that there is a tie between education and development. There are so many works that have considered the connection between education and development toward showing how the former informs the latter. Specifically, it is helpful to relay that the role of education in development of a country can hardly be over emphasized (Omeregbe $1993,36)$. Since a country is like a living organism that is made up of many parts, the various parts of a country supposed to have a specialized knowledge for its development. It insightful to note that before we proceed further to make a clarification of the concept; 'development.' the concept of national development is another way of addressing nation building. It is true that this has been variously viewed in dimension. Hence, there cannot be a one-sentence definition development (Iroegbu \& Izibili 2004, 
80). It is on this note that scholars such as John Dewey have written copiously over how education can be a transformative tool for the society. Specifically, John Dewey is convinced that:

The only true education comes through the stimulation of the child's powers by the demands of the social situations in which he finds himself...he is stimulated to act as a member of a unity...and to conceive of himself from the standpoint of the welfare of the group to which he belongs (Dewey, 1897:3).

It needs to be emphasized that for Dewey "humans are primarily social creatures and that schools are social institutions" (Ofuasia, 2019: 132). He argued that schools must represent real life and "education which does not occur through forms of life, forms that are worth living for their own sake, is always a poor substitute for the genuine reality, and tends to cramp and deaden" (Dewey, 2000: 95). While exposing the inherent aim of education, Godwin Azenabor (2005:1), explains that:

It is the most powerful and viable instrument for developing and empowering the citizens to master the social and natural environments and to compete for survival. A nation's strength largely lies in the quantity and quality of her human resources; education is the pivot on which development rotates and a fundamental capacity building measure for sustainable development.

From the exploration of the connection between education and development, it is safe to deduce that "The kind of education that one is given from childhood has a big role to play in the kind of life the person will lead" (Ofuasia, 2019: 138). It is at this juncture that this research takes a critical assessment of the political education in Africa and the suggested ways through which liberation and development have been conjectured. In the course of this research, some of the prominent African Marxists such as Claude Ake, Kwame Nkrumah, Princewill Alozie, Kola Ogundowole, Dipo Fashina will be briefly discussed before showing why their spirited defense of Marxism for Africa must be taken cautiously as lessons from the novel, Animal Farm indicates.

Animal Farm, though written almost a century ago, portrays and symbolizes the power tussle in contemporary Africa and the means to attain development that will be inclusive. My aim in this corpus is to explore how Orwell's works parallels the present clamour by Marxists in Africa for a social change that will upturn the present status quo in favour of the hoi-polloi. For my purpose, I will employ the symbolism from Animal Farm for the 'characters' in contemporary Africa. Hence, the Marxists are the pigs; the masses constitute the animals, save for the dogs who are the 'armed forces.' It does not require elaboration that the ruling class or the oppressor is Jones and other humans, in Orwell's classic.

Since the only plausible option for the Marxists is social change via violence, they have put to bitter criticisms, other possibilities which they term as reactionary and ideological propositions from the ruling class to preserve the status quo. In this connection, the political philosophy of Karl Popper is indirectly affected. I will expound on this in the next section. Afterward, I will defend Popper's approach as more appropriate with lessons drawn from Orwell (1946). I will show that the case against Popper's political philosophy is steeped in theoretical confusions and assumptions. After using Orwell's work to caution the Marxists, this study makes a case for pedagogy of political philosophy that will equip the learners with the proper mindset that will shun violence and bloodshed in the quest toward social change. 


\section{Utopian Social Engineering in Africa and the Case against Popper}

In many sub-Saharan countries in Africa, development is an ideal that is becoming unattainable. It is however, not peculiar to this part of the world alone. Some part of Asia and a most aspect of Latin America fall prey to gross maldevelopment. Poverty and hunger is at the highest toll in these regions. Let us engage this for a while. Raymond Fisman and Edward Miguel (2008: 8) inform that:

Poverty breeds desperation and discontent: we wake up daily to headlines of terrorist threats, environmental degradation, and other global ills that find their origins in Middle Eastern slums and the rainforest clear- cuts scarring the Congo River basin. Tackling the problem of global poverty is an imperative for the entire world, both rich and poor.

In the fight towards the eradication of poverty by rich and poor countries, foreign aid has usually been on the measures employed to combat this malady. It however seems that corruption and mismanagement gulps up these financial aids. In the words of Fisman and Miguel (2008:20):

Maybe corruption and violence are mainly just the symptoms of poverty. If this is the case, once rich-country donors finally send enough money to Kenya to jump-start economic growth, its citizens will no longer have to fight one another to survive. On the other hand, if most foreign aid is lost to the grabbing hands of corrupt officials or destroyed in civil strife, then how could aid dollars ever lift countries like Kenya out of poverty? More aid would just enrich an already corrupt elite, and could even make the twin problems of corruption and violence worse by giving people even more money to fight over.

Aside poverty and hunger being antecedent factors in the 'new states' of Africa, the lack of consensual political ideologies, fear of minority ethnic groupings of the majority make sincere and determined governance lose steam. This leaves out the borders created by the colonial interlopers for their administrative convenience of the 'man of colour' (Fanon, 2008) (Potholm, 1979). These realities, it has been said trigger the failure of a political ideology that is piecemeal.

This runs counter to Popper apologetic scholars who propose the perspective of 'piece-meal social engineering', wherein development and social change may be attained without bloodshed. They also seem to suggest that social democracy is the most viable alternative and paths towards sustainable development. They therefore attack any ideology with a revolutionary intent. This is contra the claims of those who share the Marxian approach.

Hence the proposition that the Popperian ideology has no bearing on African ontology. They hold a monistic picture of the world and this blurs their grasping of other kinds of reality. The point being made is that the metaphysical basis of the piecemeal social engineering may not be sufficient for the proper actualization of sustainability development in the 'New State'. As Okoro (2011) points out, the African view of reality is a dualistic monism which sees both materialism and idealism in complimentary relation and not in an antagonistic outlook. It is from this understanding we must recollect that the African approach to life has a dualistic metaphysical underpinning which is contra Western social and political philosophy, whereby you are either a materialist or an idealist.

Another Achilles Feet of the 'piecemeal social engineering' resides with the fact that the apologists of this outlook fail to take cognizance of the question of justice that plagues the current system. They recommend that peace should reign even when justice is not attended. There are many principalities that were brought together under the banner of Nigeria by the Berlin Conference that 
'shared' out Africa. Nigeria is a canopy, a creation of the colonial entities for administrative convenience. This was even an aftermath of the Berlin Conference of 1884-5 where several indigenous nations were demarcated for different colonial powers to 'possess' (Ogundowole, 2013). How can a 'piecemeal social engineer' from Popper's background respond to the question of injustice and exploitation that has plagued the peoples of the 'New States'? Would it not be reasonable to 'undo' the Berlin Conference and let the principalities that had existed hitherto, maintain their identities?

Before the interlopers, the case is that the different indigenous nation states have 'developed' in their unique ways before the era of colonization (Rodney, 2007). When we come to the Nigerian scenario and the recent call for the Sovereign National Conference, it is glaring that the crucial points that need to be addressed are left untended as they take a Popperian approach to a problem that is historically relevant. At this point of the Nigerian history, it is very glaring that the different tribes brought under the same canopy by the interlopers cannot cohabit with one another. There is always the fear, as had been hinted earlier on, of domination by one group over the other. The tribes (Isichei, 1983) in Nigeria such as Yoruba, Tiv, Efik, Idoma, Bini, Igbo, Fulani, Gbagyi, Hausa are peoples with distinct history, culture and tradition that have been disarticulated, as a result of the creation of the colonial canopy called Nigeria. Their languages are being lost as a result of the fact that they are now tutored on the language of the settlers. This is exactly what Fanon has in mind when he blurts that:

To speak a language is to take on a world, a culture. The Antilles Negro who wants to be white will be the whiter as he gains greater mastery of the cultural tool that language is. Rather more than a year ago in Lyon, I remember, in a lecture I had drawn a parallel between Negro and European poetry, and a French acquaintance told me enthusiastically, "At bottom you are a white man." The fact that I had been able to investigate so interesting a problem through the white man's language gave me honorary citizenship (Fanon, 2008: 25).

Meanwhile, language is a very powerful tool. What is the take of the National Conference on language? It is the case that the English language shall continue to be the lingua franca for people who have their own indigenous languages. This has created the problem of identity among the ethnic groups that make up the entity called Nigeria. The long term implication of this manner of thinking, Marxists forecast is the modeling of our thoughts with those of the West. This fact is also corroborated by D. Westermann who exposes that "the wearing of European clothes...adorning the Native language with European expressions, using bombastic phrases in speaking or writing a European language; all these contribute to a feeling of equality with the European and his achievements" (Westermann, 1976: 331). Even Wittgenstein (1963) shares a similar take on the subject matter of language. On the authority of Anthony Kenny, Ludwig Wittgenstein harps: "in the very language we use there is a philosophy which bewitches us. This philosophy is not a set of theories or propositions: it is embodied in the misleading nature of the grammar of natural languages, which disguises the actual way in which words are used" (Kenny, 2006: 371). Implied in this excerpt is the glaring admonition from Wittgenstein that every language is laden with its philosophy. Here, Marxists clamour that the present status quo, does Africa no good.

Marxists in Nigeria such as Princewill Alozie, Kola Ogundowole, Dipo Fashina insist that mainstream Western social science and frame of a political philosophy like Karl Popper's are opposed to dialectical change that will upset the exploitative status quo. Fashina (1989) is even more outspoken 
when he justifies the use of violence in social change. He endorses Fanon by stressing that humanism is not a universal phenomenon since "...violence....were instrumental to Europe's colonization and enforced occupation of the African continent" (Hallen, 2004: 132).

While Karl Popper speaks of social change, he fails to note that social change must occur as a result of contradictions in society, the Marxist points out. A political ideology as Popper's is more interested in maintaining the status quo, for the Marxists. Popper's ideas are no different from the ones that implore Africans not to use violence which was used in the first place to supplant them (Fashina, 1988). Hence, Popper's strand of philosophy is tangentially geared toward the preservation of order rather than change. This charge also extends to Western social science scholarship on Africa. While reacting to the bulk of Western social science scholarship, which does not preclude Popper's, on social change, the late Claude Ake (1981: 4) retorts:

This device did not teach us anything about social change but merely revealed further the ideological bias of Western social science, for what the procedure in question was really drawing attention to was that the Western societies were at the peak of social evolution and that in so far as other societies needed change, the real question was how far they could be like the West. As if to stress this ideological bias and the fundamental lack of interest in change, the new development approached hardly raised the question as to how the preferred categories (Western societies) might change. These types of problem have hampered students of Africa who are studying societies where change is particularly ubiquitous.

Marxists like Nkrumah (1964) explains that scholars, on the subject of development and change on the African continent take hook, line and sinker the ideological assumptions from Western scholarship, without due critical assessments. Ake (1982) calls this tendency 'technicism'. The 'New States,' as they currently are, need a holistic kind of social change contra what Popper project, Ogundowole (1988) explains. This kind of change is one that would take cognizance of their pasts; an overcoming of the traditions and conditions that garnered peoples of different backgrounds for ease of colonial administration; and the need to face the question of different afresh from a real sovereign perspective away from Western interference.

For instance, the ideological philosopher and statesman, a Marxist to the core, Kwame Nkrumah proposes that the Utopian route change is what Africa needs. Africans must unite to face the common foe via the Utopian approach, which is thoroughly Marxist in nature. He expresses this in his philosophy of consciencism. The viewpoint of consciencism is that philosophy arises from and operates within the context of a given society. This viewpoint asserts that "philosophy always arose from social milieu and that a social contention is always present in it" (Nkrumah, 1964: 10). Nkrumah was in search of an ideological catalyst for development. He was seeking an ideology that shall be a synthesis of traditional and modern elements, that is, a synthesis of past and present. However, Consciencism, as simply illustrated above reinforces an earlier position redolent in the educator Edward Blyden on African culture. It also upheld many of the ideological assumptions hitherto held by Nkrumah, particularly his denial of class conflict in pre-colonial Africa.

Nkrumah's Philosophical Consciencism, emphasizes that traditional African society was an egalitarian and communal society in which the means of production, including land, were held in common and individual ownership did not exist (Biney, 2011: 125). Inadvertently, prior to Nkrumah, 
Blyden had articulated similar thoughts on Africa's cultural strains in his work Christianity, Islam and the Negro Race. Blyden advocated that African civilization had its own validity and was a universal part of civilization. It was characterized by communal African life, a community characterized by cooperation and mutual aid, and a communion with nature and God (Biney, 2011: 125). But how does consciencism as a development ideology filter into the development discourse of Nkrumah?

In clear terms, given Nkrumah's assumptions that traditional African was egalitarian, then it must affirm socialism. This is because socialism too breeds egalitarianism. And from consciencism, egalitarianism equals materialism. Hence, traditional Africa, Nkrumah claims, was materialistic. Kwame Nkrumah believes in the African past which is egalitarian and materialistic as opposed to the idea of capitalism, an introduction by colonialism, which is idealistic. He therefore takes strongly the idea of African Socialism by conversing for communalism. In other words, Nkrumah continued to maintain the view that communalism is characteristic of African society. He referred to "the spirit of communalism" (Nkrumah, 1964: 70) as what pervades African society. In his own words:

Socialism, therefore, can be and is the defence of the principles of communalism in a modern setting. Socialism is a form of social organisation, which, guided by the principles underlying communism, adopts procedures and measures made necessary by demographic and technological developments. These considerations throw light on the bearing of revolution and reform on socialism. The passage from the ancestral line of slavery via feudalism and capitalism to socialism can only lie through revolution: it cannot lie through reform. For in reform, fundamental principles are held constant and the details of their expression modified. In the words of Marx, it leaves the pillars of the building intact. Indeed, sometimes, reform itself may be initiated by the necessities of preserving identical fundamental principles (Nkrumah, 1964:73-74).

The above are the tenets of Consciencism set out in a very brief manner. This does not mean that Nkrumah's philosophy is not without its own problems. It is doubtful if Africans are strictly materialistic and also egalitarian as he wants us to believe. This system necessarily opposes the idealistic and exploitative system of colonialism and exploitation, hence the need to return to regurgitate this traditional outlook for contemporary utility. Impliedly, this is the kind of exploitative status quo that the philosophies of the strand of Popper seek to preserve, Marxists will propose.

\section{Karl Popper's Anti-Violence and Piecemeal Social Engineering: An Orwellian Defense}

Karl Popper wrote against philosophic sages like Plato, Friedrich Georg Wilhelm Hegel and Karl Marx amassing reasons and marshalling arguments for why it is not a choice to practice social democracy with full weight resting on individualism, but an imperative. The thrust of his ideas is to structure society and social change in such a ways that violence and similar activities that inform bloodshed may be avoided.

Karl Popper had so many influences on his thoughts such that it would be difficult to proceed without mentioning prominent names, including those he took to the grinder in the form of criticisms Plato, Hegel, Marx. This does not however mean that Popper did not influence. Peter Singer also says something similar on the subject matter, when he reveals that:

There are philosophers interested in logic or philosophy of science, like William Kneale, W.V. Quine, Hilary Putnam, A.J. Ayer, and Thomas Kuhn; distinguished scientists discuss the bearing of 
Popper's thought on fields like physics, psychology, and neurophysiology; John Wild criticizes Popper's interpretation of Plato, and H.B. Acton has sent in an essay vaguely related to what Popper wrote about Marx; Edward Boyle, who might have been Britain's Minister of Education had he not been too liberal for his Conservative colleagues, tries to say what Popper's political ideas meant for him as an active politician; there are essays on Popper's case against determinism, his views on the nature of time, and his theory of method in the social sciences; Ernst Gombrich completes the diversity by using some of Popper's remarks to illuminate the history of art (Singer, 1974).

In The Open Societies and its Enemies, The Poverty of Historicism as well as in some sections of Conjectures and Refutations Karl Popper, Karl Popper uses 'piecemeal social engineering' and 'utopian social engineering' to designate attempts to reform society. He contends against Plato whose ideal of the state is a doctrine of the wise management of society ensuring the perfect embodiment of absolute justice, absolute truth and absolute beauty, thanks to which a social system will be established in which every man will occupy the place assigned to him, whether he be craftsman or farmer, guardian or ruler-philosopher (Oizerman, 1973:30-1).

For Popper, Plato's historicist ideas are driven by a fear of the change that comes with such a liberal worldview. Popper also suggests that Plato was the victim of his own vanity, and had designs to become the supreme Philosopher King of his vision. Popper maintains that it is more than a theory but a form of manifesto in which a self-portrait lies hidden behind the picture of the ideal sovereign (Corvi, 2005: 59). This is well captured in the words of Popper thus:

The philosopher king is Plato himself, and the Republic is Plato's own claim for kingly power - to the power which he thought his due, uniting in himself, as he did, both the claims of the philosopher and of the descendant and legitimate heir of Cordrus the martyr, the last of Athen's kings (Popper, 1966: 153).

After all these, Popper submits his own philosophical explorations on the necessity of democracy as the only form of government allowing institutional improvements without violence and bloodshed.

In volume two, Popper attacks Hegel and Marx, tracing back their ideas to Aristotle, and arguing that the two were at the root of 20th century totalitarianism. In his own words, "the real issue is 'how' and not 'who' when wants to define modern democracies" (Popper, 1966: 121). This idea may also be scanned in his The Poverty of Historicism.

Popper defines historicism as an approach to the social sciences which assumes that historical prediction is their principal aim (Popper, 1957). Hence, the thinking that it is the task of the social sciences to lay bare the law of evolution of society in order to foretell its future... might be described as the central Historicist doctrine (Popper, 1957). Focusing on Karl Marx, Popper writes elsewhere that "Marx is a rigid determinist who thought he had discovered the inexorable laws that control our destiny, laws in the face of which we are mere puppets irresistibly pulled by economic wires" (Popper, 1966:101).

Karl Popper is "among those who have prominently defended science as a model for the conduct of liberal democracy" (Guignon and Hiley, 2003) since he is a thorough-going liberal. There has been much dispute about how his method of science can be brought to bearing in the field of politics. John Gray in a similar mould highlights that: 
The nature of the relation between Popper's philosophy of science and his political philosophy has always been one of the most disputed aspects of his thought. Since it is one of the central theses of Popper's critics that his political philosophy consorts badly with his account of scientific method - in that Popper appears to commend permanent revolution in science while favouring incremental reformism in political life - it is vitally important that we settle the prior question whether the two parts of his philosophy are indeed logically related (Gray, 1976: 2).

It is the belief of Karl Popper that freedom of thought and free discussions are ultimate liberal values which needs no justification. If this is the case, then we are led to ask why he questions the justification of totalitarian regimes if he does not want to critically scrutinize that which he supports. In his own words, while articulating his case on liberalism and democracy, Karl Popper hints that "the difference between a democracy and a tyranny is that under a democracy the government can be got rid of without bloodshed; under a tyranny it cannot" (Popper, 1963). Popper says that democracy "provides the institutional framework for the reform of political institutions. It makes possible reform of institutions without using violence, and thereby the use of reason in the designing of new institutions and the adjusting of old ones" (Popper, 1966: 126). Hence, under-performing 'institutions' cannot be blamed on democracy (being an ideal), Popper insists. Democracy does not guarantee the intellectual standards of individuals; this is a personal problem (Corvi, 2005: 61). He puts it clearly in his words thus

It rests with us to improve matters. The democratic institutions cannot improve themselves. The problem of improving themselves is always a problem of persons rather than for institutions. But if we want improvements, we must make clear which institutions we want to improve (Popper, 1966: 127).

He responds to the age old criticism of democracy as rule of the mob in the following words: "We are democrats, not because the majority is always right, but because democratic traditions are the least evil ones of which we know. If the majority (or 'public opinion') decides in favour of tyranny, a democrat need not therefore suppose that some fatal inconsistency in his views has been revealed. He will realise, rather, that the democratic tradition in his country was not strong enough" (Popper, 1963: 98).

African socio-political writers and ideological banks, tainted by Popperian ideology hold dear to the 'Piecemeal Social Engineering' (liberalism and democracy as opposed to totalitarianism) as a panacea to Africa's problems. This breeds a sharp conflict between them and Marxian ideological scholars on the continent who subscribe to a politico-economic overhauling, what Popper (1945) calls 'Utopian Social Engineering.' In this regard, this essay focuses on the need to caution the Marxian approach to social change which is both utopian and violence. Rather than exploring the violent approach, the piecemeal may be observed since the original intent of some of these marxists are not even readily known to the masses. At this juncture, drawing parallels with the theme of Orwell's Animal Farm becomes crucial.

In the aftermath of the 'revolution' at Manor Farm and the succession to the 'power hierarchy' by the pigs, later headed by Napoleon, one would inquire into the lot of the other animals whose rational capacity seems to be on holiday. This is a case to ponder over in George Orwell's Animal Farm: A Fairy Story. Much as deception was very easy to attain after the aphorism: "four legs good, two legs 
bad" migrated into "four legs good, two legs better", the reader is left to wonder why the other animals were so daffy (Orwell, 1946). Even when Clover seems to recall the initial cliché, she could not trust her memory. I think the only Socrates in that insightful work is Old Benjamin. Perhaps, he must have heard about the Athenian Socrates, so kept his thoughts to himself to avoid the hemlock. You will need to congratulate Squealer, whom I dub the minister of information. He committed several fallacies and proposed seemingly convincing arguments but the poor minds of the other animals would not decipher. Napoleon and his arch-rival Snowball made the early parts of the novel interesting. But the other players, constituted by the porous and fickle-minded animals were not only confused but lacked the intellectual will to comprehend the status quo clearer. Their minds are far from being roused!

In Orwell's analysis, the Marxists are the pigs; the masses constitute the animals, save for the dogs who are the 'armed forces.' It does not require elaboration that the ruling class or the oppressor, are the humans. From this, I will proceed to analyse the concept of change from the Marxists that needs to be watched.

There are other farms aside Manor in Orwell's classic. Manor Farm is owned by Jones, the perceived oppressor who mirrors as the ruling class. Jones and everything that stands for humans in the novel was perceived as both ruling class and oppressor within and outside Manor farm. It is up to the pigs to then initiate the class distinction albeit implicitly. The animals all suspect something was wrong but they could not actually pin what is amiss. Marxists usually have the source of their ideology. The ideology from this source, they respect and perceive to be very correct about the past, present and the future. Old Major, the oldest pig depicts the real Karl Marx since he set out the class distinction to the understanding of the animals and hoped for the day when the beasts of England will prevail of humans. This is actually Marxists' admission that the present status quo will soon be overturned against the ruling class for the benefit of common people. Old Major's speech continues to motivate the animals. Throughout the novel, it seems this speech is the only idea the animals understood but lacked the will and resolve to lead, hence the mantle passed to the pigs.

The revolution was bloody but all the promises made to the animals soon started to dwindle and shrink especially when the 'dogs,' the armed forces entered the fray. Napoleon who was seen as a friend and leader soon assumed powers that become questionable only at the price of the dogs' bite. Soon, with the use of rhetorics, the commandments of Animalism were fritted away on private gains. It is within this spectrum that Africans must be careful of Marxists in Africa. At this juncture however, I must stress a point. Marxism as an ideology is not entirely bad in itself. Just like democracy is not entirely bad in itself, Popper says: "It rests with us to improve matters. The democratic institutions cannot improve themselves. The problem of improving themselves is always a problem of persons rather than for institutions. But if we want improvements, we must make clear which institutions we want to improve" (Popper, 1966: 127). This line of thinking can also be brought into Marxism in Africa. The ideology is not bad in itself. It is however important to look at the problem of persons who take the mantle of leadership and inquire if these people will not actually end up dining with the common enemy. This is the cautious question that should be burning in the minds of Africans

There have been reported cases of labour union representatives who agitate for the welfare of the masses to the ruling class and seeking to strike a balance of equity. Most of these union leaders are immersed in the Marxists ideology of class and struggles of the classes. They are usually Marxists with 
the deep passion that the socialist system will in a short while upturn the status quo. This is keeping in line with Theses on Feuerbach where Karl Marx announces that "philosophers have interpreted the world in various ways, the point however, is to change it" (Marx, 1972:220). So this is where I have a problem and caution the masses to be wary of Marxists.

The passion to change and engineer society is worthy. However, the violent approach which Popper cautions is a step taken too far. It is my agreement with Popper, and for the awareness of the public that no blood of any citizen be sacrificed for social changes that could have taken a peaceful and non-violent route. While seeking the easiest route to social change, Popper advocates for the piecemeal and peaceful alternative democracy. Democracy is much better than the kind of tyranny that the Marxists approach as illustrated with Animal Farm may lead to. Hence for Popper: "the difference between a democracy and a tyranny is that under a democracy the government can be got rid of without bloodshed; under a tyranny it cannot" (Popper, 1963). On democracy, Popper explains that it "provides the institutional framework for the reform of political institutions. It makes possible reform of institutions without using violence, and thereby the use of reason in the designing of new institutions and the adjusting of old ones" (Popper, 1966: 126). This is the caution for the masses to be wary of Marxists in Africa who uphold the principle of change via violence and bloodshed as though there are no other plausible means to explore. At this juncture, it is important to provide some recommendations for political education that will birth social change without bloodshed.

\section{Conclusion}

This study defends Popper against the shades of ideas that Marxism and Marxists in Africa perceive as reactionary, preserver of the status quo. I offer that if the status quo may be changed it should not explore the approach of violence as a necessary and conclusive when there are ways to actually change political institutions without harming a soul. Furthermore, I argued that there are instances where Marxists usually empathise with the people, emphasize on the class distinction only for them to attain power unto themselves to become totalitarian and despotic. Germany's Adolf Hitler and Italy's Benito Mussolini readily comes to mind. Animal Farm and the lives of Hitler and Mussolini have provided a window into the future of such struggles for change which comes at great price only for a totalitarian regime to be installed. Hence, it is the emphasis of this study that Marxists in Africa leading struggle on the continent should be given a critical gaze because in most instances, their intents are deeply opposed to the masses' even when on the surface, the connection is in tandem. For this to be attained, the following recommendations can be helpful:

(1) This research maintains and agrees to previous perspectives that education has a role in the formation of minds that can transform society. However, when education becomes indoctrination, the entire effort toward social change may be compromised. It seems most of the Marxists in Africa are given to indoctrination rather than education. This accounts for some of the reasons why other nonviolent ways of social change have yet to be seen as progressive. This orientation needs to be revised and education of the minds from the tender age can be very useful;

(2) Another interesting recommendation which the present research focuses over is that social practices and policies are reflections of her education. Under this understanding, this research suggests that proper investment be given to education aimed at reconstructing society. This has always 
been the view of scholars such as John Dewey, Friedrich Froebel, Julius Nyerere, to name a view. In places like Africa where funding for education is constantly declining, it is the submission here that for Africa to overcome the tides of underdevelopment, proper investment in her education sector cannot be negotiated; and

(3) This study recommends the need to understand that political instability and economic challenges can only be solved through theories of political economy. A critical exploration of the ways through which education informs social realities, using the imageries of Orwell's Animal Farm, is a testament to how a multidisciplinary approach to social maladies can be addressed. On this note, education cannot be a push over.

\section{References}

Ake, C. (1982). Social Science as Imperialism: The Theory of Political Development. Ibadan, Spectrum Books.

Ake, C. (1981). A Political Economy of Africa. Nigeria, Longman Group Limited.

Azenabor, G.E. (2005). Sustainability of University Education in Nigeria: A Philosophical Discourse on Problem and Revival Strategies. In Ogbinaka, O.M. (ed.), African Studies Monographs, No.VI., Onosomegbowho Oginanka Publishers Ltd.

Biney, A. (2011). The Political and Social Thoughts of Kwame Nkrumah. New York: Palgrave Macmillan

Corvi, R. (2005). An Introduction to the Thought of Karl Popper. Trans P. Camiller. London: Taylor and Francis

Dewey, J. (1897). My Pedagogic Creed, New York and Chicago: E.L. Kellogg \& Co.

Dewey, J. (2000). My Pedagogic Creed. In Reed, R.F. \& Johnson R.W. (eds.) Philosophical Documents $n$ Education. New York: Longman.

Gray, J. (1976). The Liberalism of Karl Popper. Philosophical Notes, London, No. 9.

Fanon, F. (2008) [orig. 1952] Black Skin White Mask, London, Pluto Press.

Fashina, D. (1988). Marx, Moral Criticism and Political Choice. The Philosphical Forum. XIX (4) Summer: pp. 291-308.

Fashina, D. (1989). Frantz Fanon and the Ethical Justification of Anti-colonial Violence. Social Theory and Practice. 15 (2).

Fisman, R., \& Miguel, E. (2008). Economic Gangsters: Corruption, Violence and the Poverty of Nations. New Jersey, Princeton University Press.

Guignon, C., \& Hiley, D.R. (eds.). (2003). Richard Rorty: Contemporary Philosophy in Focus. New York, Cambridge University Press.

Hallen, B. (2004). Contemporary Anglophone African Philosophy. In K. Wiredu (ed.). A Companion to African Philosophy. New York: Blackwell.

Iroegbu, P.O. \& Izibili, M.A. (2004). Kpim of Democracy Thematic Introduction to Socio-Political Philosophy. Benin-City: Ever-Blessed Publishers

Isichei, E., (1983). A History of Nigeria. London, Longman.

Kenny, A. (2006). An Illustrated Brief History of Western Philosophy. New York, Blackwell Publishing Ltd.

Marx, K. (1972). Theses on Feuerbach. In Selected Woks of Marx and Engels. New York: International Publishers. 
Nkrumah, K. (1964). Consciencism: Philosophy and Ideology for Decolonization. London: International Publishers

Ofuasia, E. (2019). A Comparative Exploration of John Dewey's and Julius Nyerere's Concepts of Education and African Development. Philosophy of Education, 25(2), 127-141. DOI: https://doi.org/10.31874/2309-1606-2019-25-2-7

Ogundowole, E.K. (2013). Towards Negotiating Nigeria for Nigerians (2). The Punch Newspaper. www.punchng.com/opinion/towards-negotiating-nigeria-for-nigerians-2.htm, published July 3, 2013.

Oizerman, T. (1973). Problems of the History of Philosophy, Moscow: Progress Publishers.

Ogundowole, E.K. (1988). Self-reliancism: Philosophy of a New Order. Lagos: John West

Omoregbe, J.I. (1993). ETHICS: A Systematic and Historical Study. Lagos: Joja Educational Research and Publishers Ltd

Orwell, G. (1946). Animal Farm: A Fairy Story. New York: Harcourt, Brace \& Company.

Potholm, C.P. (1979). The Theory and Practice of African Politics, New Jersey, Prentice Hall.

Popper, K.R. (1966). The Open Society and its Enemies. Vol 1., The Spell of Plato. New Jersey: Princeton University Press.

Popper, K.R. (1963). 'Public Opinion and Liberal Principles' in Conjectures and Refutations, London, Routledge and Kegan Paul.

Popper, K.R. (1957). The Poverty of Historicism, Routledge and Kegan Paul.

Rodney, W. (1972). How Europe Underdeveloped Africa, Darees Salaam, Bogle-L'Overture.

Singer, P. (1974). Discovering Karl Popper. The New York Review of Books, 21, 7.

Westermann, D. (1976). African Today, Oxford, Clarendon Press.

Wittgenstein, L. (1963). Philosophical Investigations. G.E.M., Anscombe and R.Rhees, (eds.) Oxford: Blackwell. 


\section{Освіта та соціальні зміни в роботах Карла Поппера та Джорджа Оруелла: педагогіка застереження щодо марксизму в Африці}

Dasaolu, Babajide Olugbenga, Department of Philosophy, Olabisi Onabanjo University,Ago-Iwoye, Ogun State, Nigeria

Кілька десятиліть тому бразильський вчений Пауло Фрейре в роботі «Педагогіка пригноблених» описав роль освіти в прочесах соціальних змін. У дослідженні вивчається робота Фрейре, а саме діалог про те, як автентичні та орієнтовані на людей соціальні зміни можуть бути реалізовані в Африці. У сучасній африканській політичній научі вчені розходяться щодо методології досягнення соціальних змін. Деякі черпають натхнення з думок Карла Поппера, який стверджує, що існують два підходи до суспільних змін, і коли через призму його вчення розглядати марксистів Африки, то їх підхід має утопічний характер. Оскільки домінуючим підходом щодо соціальних змін серед африканських вчених є марксизм, це дослідження є певним застереженням. Треба бути обережними, тому що марксисти африканського походження дуже критично ставилися до версії соціальних змін Поппера через реакційність; вважають, що його точка зору спрямована на збереження експлуататорського статус-кво. Задачею даного дослідження є захист теорії Поппера від викривлень. В дослідженні також розглянуто класичну “рерму тварин» Джорджа оруелла, щоб допомогти через цю історію розкрити небезпеки, які можуть виникнути від утопічної соціальної інженерії в реальному житті. Тоталітарна епоха, яка настала в світі тварин після їх насильницької та кривавої револючії на фермі, є не лише уроком, а й поштовхом для розмірковування над тим наскільки чесні наміри у тих, хто відповідає за соціальні зміни та боротьбу в Африці. Саме з цієї причини автор робить висновок щодо необхідності створити платформу для соціальних змін без насильства та кровопролиття. Використовуючи педагогічний підхід до освіти, це дослідження вивчає способи за яких освіта сприятиме соціальним змінам і соціальній стабільності в Африці.

Ключові слова: Карл Поппер, сочіальні зміни, марксизм, Африка, Джордж Оруелл 